sitism and Symbiosis" and "Skeletons, Shelters and Special Defences". There is no mention - and could not be without extension into a second volumeof reproduction, which one feels should be covered in any book dealing with biology. Dr. Nicol might have been better advised to restrict himself to his purely physiological chapters - with suitable change in title-because the final two chapters covering much wider, less-analysed fields are inevitably more condensed and less critical.

These, however, are very minor criticisms of a book that brings many into Dr. Nicol's debt. It is extremely well produced, containing some 300 figures as well chosen as they are reproduced. The publishers may well share some of the congratulations extended to the author but not, surely, when it comes to price. Was it, one may reasonably ask, really neces. sary to charge almost $£ 5$ for a book that should find a place in the library of every university and marine station in the world and be in the possession of everyone scientifically interested in marine animals?

C. M. YoNGE

\section{A NEW STUDY OF THE BRITISH ODONATA}

\section{Dragonflies}

By Philip S. Corbet, Cynthia Longfield and N. W. Moore. (The New Naturalist: a Survey of British Natural History.) Pp. xii $+260+32$ plates. (London : William Collins, Sons and Co., Ltd., 1960.) $42 s$. net.

W ${ }^{\text {ITH }}$ just over forty species of dragonflies recorded from the British Isles, one might at first question the necessity for another book on these insects, since for the purposes of identification the subject has already been dealt with in two recent publications. The present volume in the "New Naturalist" series is, however, intended more for the naturalist than for the collector and may be considered rather as supplementary to Tillyard's classic, "The Biology of Dragonflies," in which the external and internal morphology of the Odonata was dealt with in great detail, but classification, distribution, fossil history, bionomics, etc., only occupied about one-third of the book. As in other volumes of the "New Naturalist" series, this book is an indication of the changed attitude of the naturalist, with the emphasis on the living insect and its behaviour rather than on dissection and museum study.

Three of its fourteen chapters deal with the composition of the British dragonfly fauna, its history and distribution, and four are devoted to the life. history of the various stages. The behaviour of the adult dragonflies, dispersal and seasonal regulation in dragonflies are the titles of other chapters, and the fossil history of the order and the inter-relationships of dragonflies and other animals (including man) are discussed. Various appendixes include a key to the larvæ of the British dragonflies, a survey of the wing venation and its terminology, methods of preserving colours of dragonflies and of marking dragonflies for behaviour studies.

The three authors are all general naturalists as well as being specialists in different facets of the study of Odonata. Dr. P. S. Corbet made a threeyear investigation into various aspects of the lifehistory of dragonflies the subject of a thesis for his
Ph.D. degree. Miss C. Longfield worked for thirty years as an honorary associate in the Department of Entomology, British Museum (Natural History), where she identified and described dragonflies from many parts of the world, including material collected on her own expeditions abroad. Dr. N. W. Moore made his investigations into the ecology and behaviour of adult dragonflies the basis of his Ph.D. degree, and has also studied Odonata in the field in Gambia.

These three authors, each being responsible for different sections of the book, have succeeded in welding their contributions into a homogeneous and very readable whole, without suppressing too much of their individual styles and personalities. Much of the information in the chapters on life-history and bchaviour is based on the authors' personal studies, and the occasional use of the first person singular gives life to their accounts and prevents them from appearing too formal to the general reader. The inclusion (as an appendix) of Mr. A. E. Gardner's keys to the larvæ of British dragonflies, with his own illustrations, is a valuable addition to the book. These keys originally appeared in an entornological journal, and their reprinting here will introduce them to a wider public.

The production is entirely up to the standard of the previous volumes, and the work is fully illustrated with plates in both colour and in monochrome and with some line drawings. The line drawings in the chapter on behaviour are an excellent example of how to use bold, simple drawings. There are many colour plates, most of them reproduced from very fine transparencies specially taken by $\mathrm{Mr}$. S. Beaufoy. These were mostly taken under controlled artificial light conditions and are in a sense studio portraits of the living insects. By this means a more uniform colour balance has been obtained, and the background can be chosen to suit the subject. All these colour plates are reproduced at natural size, and while this is an advantage for comparison, it does mean that the smaller specimens lose a certain amount of detail in reproduction. This is particularly noticeable where, as in one or two illustrations in the review copy, one of the colour impressions is slightly out of register. One realizes that to have reproduced the smaller species on a larger scale would have entailed more colour plates and an increase in cost.

As a whole, this is a most interesting book and one which should prove extremely useful not only to students of dragonflies but also to field naturalists and to students, as it not only gives a recent picture of the state of our knowledge of the British Odonata but also shows in what directions further research is needed.

D. E. Krmmins

\section{GROWTH AND FORM IN AN INSECT}

The Control of Growth and Form

A Study of the Epidermal Cell in an Insect. By Prof. V. B. Wigglesworth. Pp. vi +140 . (Ithaca, New York: Cornell University Press; London: Oxford University Press, 1959.) 21s. net.

rHIS well-illustrated small book, based on six Messenger Lectures which Prof. V. B. Wigglesworth delivered to a general audience at Cornell University in 1958, displays the epidermal cell of an insect as a medium convenient for the 